\title{
Neutrophil Gelatinase-associated Lipocalin (NGAL) \\ a Promising Biomarker for Early Detection of Nephrotoxic Injury
}

\author{
ALEXANDRU-IOAN ULMEANU ${ }^{1,2 *}$, ISABEL GHITA ${ }^{3}$, CORIOLAN ULMEANU ${ }^{1,2}$ \\ ${ }^{1}$ Carol Davila University of Medicine and Pharmacy Bucharest, Faculty of Medicine, Department of Pediatrics, 8 Eroilor \\ Sanitari Str., 050474, Bucharest, Romania \\ ${ }^{2}$ Grigore Alexandrescu Emergency Children's Hospital, Department of Toxicology, 30-32, Bd Iancu de Hunedoara, \\ Bucharest, Romania \\ ${ }^{3}$ Carol Davila University of Medicine and Pharmacy Bucharest, Faculty of Medicine, Department of Pharmacology and \\ Pharmacotherapy, 8 Eroilor Sanitari Str., 050474, Bucharest, Romania
}

\begin{abstract}
Renal toxic injury can neither be predicted nor quantified exactly by the serum creatinine level. NGAL is a promising biomarker for early detection of AKI due to different causes. Our objective was to evaluate it's value in the setting of nephrotoxic injury. We performed an experiment in which we administered gentamicin, atropine and fipronil at different doses to the laboratory mice to quantify the evolution of creatinine and NGAL. Compared to creatinine, NGAL increased faster and was detected at elevated levels from the first $4 \mathrm{~h}$ after administration of both low and high dose gentamicin. Fipronil, atropine and the combination caused a significant increase in NGAL serum values at 4 hours, an increase that lasted up to 24 and $72 \mathrm{~h}$, respectively, compared to the control group, Its highest levels were recorded at $4 \mathrm{~h}$. Compared to creatinine, NGAL increased faster and was detected at elevated levels from the first $4 h$ after administration of fipronil, atropine and the combination of them.
\end{abstract}

Keywords: NGAL, neutrophil gelatinase-associated lipocalin, acute kidney injury, nephrotoxic

Nephrotoxic injury is not always clinically apparent, so laboratory tests are essential for diagnosis. Toxic renal damage may be suspected in the case of urinary volume changes, but oliguria is not always present. Acute kidney injury (AKI) represents the sudden loss of renal function reflected by a decrease in glomerular filtration rate (GFR), increased creatinine and blood nitrogen levels, and failure of the hydroelectrolytic homeostasis regulation of the kidney (1-3).

Functionally lipocalins are transport proteins, they contain a 20 aminoacid signal peptide and the lipocalin domain. The domain helps binding lipocalins to their ligands. This structurally includes an eight stranded $\beta$ barrel with its loops running in an antiparallel direction. The lipocalin transports low molecular chemicals $(4,5)$.

Crystalographic studies have demonstrated the high affinity of NGAL for binding bacterial siderophores and for the first time NGAL was discovered as a neutrophil granule component. It is demonstrated that NGAL can be found in lots of human tissues like liver, lung, kidney, small intestine, bone marrow, prostate, adipose tissue and macrophages. NGAL main function is acting as a bacteriostatic agent, by binding to bacterial siderophores it restricts the iron needed by bacteria for growth. (6-8) NGAL is also a chemoattractant for neutrophils and an inhibitor of oxidative stress. (9) Toxins and ischemia are very frequent involved in developing AKI. (10). Early during AKI high levels of NGAL are detected. Animal experiments suggest that NGAL could reduce apoptotic tubule cell death (11). NGAL can lessen the renal injury and inhibit epithelial cell apoptosis via Bcl2/Bax signaling pathways (12-16).

A child in the early stages of severe AKI with a significantly reduced GFR could have relatively normal or slightly elevated creatinine values because there was not enough time for it to accumulate. In addition, creatinine is removed by dialysis, it can not properly evaluate the renal function once dialysis has started. Despite these limitations, serum creatinine continues to be the most commonly used laboratory test for the diagnosis of AKI in children (17-18).

\section{Objective}

Renal toxic injury can neither be predicted nor quantified exactly by the serum creatinine level. The occurence of acute renal injury during children poisoning increases mortality, increases the duration of hospitalization and aggravates the long-term prognosis of patients so early and correct recognition of AKI is essential for the correct assessment of intoxication cases. We need novel markers for early detection of AKI in children poisoning. NGAL is a promising biomarker for early detection of AKI due to different causes. Our objective was to evaluate it's value in the setting of nephrotoxic injury (19-23).

*email:alexandru.ulmeanu@umfcd.ro 


\section{Experimental part}

Material and methods

Experiment 1

45 Wistar SPF (specified pathogens free) rats were used purchased from the Cantacuzino Institute and divided into 3 groups as follows:

Group A - control group - 15 rats - which were injected intraperitoneal (ip) with $0.1 \mathrm{~mL} / \mathrm{kg}$ ip solution control physiological serum (group M)

Group B - test group - 15 rats - tested with gentamicin $25 \mathrm{mg} / \mathrm{kg}$. ip (group G1) for three days

Group C - test group - 15 rats - tested with gentamicin $75 \mathrm{mg} / \mathrm{kg} . i p$ (group G2) for three days

\section{Experiment 2}

60 Wistar SPF (specified pathogens free) rats were used, purchased from the Cantacuzino Institute which were divided into 4 groups as follows: M)

Group M - control group - 15 rats - which were injected ip with $0.1 \mathrm{~mL}$ normal saline / 100g body weight (group

Group B - test group - 15 rats - $7.5 \mathrm{mg} / \mathrm{kg}$ fipronil administered by oral gavage (group B)

Group C - test group - 15 rats - atropine tested $28 \mathrm{mg} / \mathrm{kg}$ administered ip. (group C)

Group D - test group - 15 rats - tested with the combination of oral fipronil $7.5 \mathrm{mg} / \mathrm{kg}$. body + atropine i.p. $28 \mathrm{mg}$ / kg body weight (group COMB)

The rats were housed in groups of three in plexiglass cages whose floor was covered with absorbent specimens and were brought into the laboratory 5 days before the experiment for acclimatization. Throughout the experiment the rats had ad libitum access to food and water. Rat cages were housed in the same room throughout the experiment with maintaining a relatively constant temperature $\left(\sim 22^{\circ} \mathrm{C}\right)$.

\section{Substances used:}

- normal saline solution

- gentamicin solution for injection $80 \mathrm{mg} / 2 \mathrm{~mL}$ (Biochemie)

- fipronil solution $0.25 \mathrm{~g} / 100 \mathrm{~mL}$ (Merial)

- sulfuric atropine (Sigma-Aldright)

- the combination of fipronil-atropine (COMB)

\section{Parameters monitored}

Rats were weighed and monitored daily from the point of view of general appearance (fur, mucous membranes, snout, ears) in the event of appearance or behavior changes. According to the protocol of work in the 3 moments of the experiment blood samples were collected and serum creatinine (crea) and NGAL (neutrophil gelatinase-associated lipocalin) were measured. Blood samples were collected after $12 \mathrm{~h}$ of fasting. Biochemical determinations were performed by MedCenter SRL (possessing RENAR accreditation).

The rats were anesthetized with diethyl ether to ensure rapid installation and lasting anesthesia as well as easy recovery from anesthesia. The blood samples were collected by puncture of the retroorbital sinus with the help of Pasteur glass pipettes with $145 \mathrm{~mm}$ length. With the tip of the pipette, the puncture of the retroorbital venous plexus was performed collecting $1.5 \mathrm{~mL}$ of blood. The blood was harvested in serum separator tubes. Serum determinations of NGAL were done by ELISA method.

Statistical results were calculated by computing standard averages and deviations. Statistical significance testing was performed using the t-Student test. For statistical analysis of the data we used Microsoft Excel 2010.

All the experiments described in this article were carried out in 2012 in the experimental laboratories of UMF Bucharest in accordance with The European Directive 86/609/EEC/24.11.1986 and The Romanian Government Ordinance 37/30.01.2002 regarding the protection of animals used for experimental and other scientific purposes.

\section{Results and discussions \\ Experiment 1}

Gentamicine $\left(\mathrm{C}_{21} \mathrm{H}_{43} \mathrm{~N}_{5} \mathrm{O}_{7}\right)$ is an antibiotic that belongs to the aminoglycoside group. The renal toxic effect of aminglycosides is not fully understood. Aminoglycosides form reactive oxygen species that cause lipid peroxidation. They destroy phospholipids contained in the brush border membrane of proximal tubules, the lumen is obstructed with celluar debris and renal impairment occurs. Early after administration we can observe a raise in the dimensions and number of the lysosomes, they contain lamelar structures that represent undegraded phospholipids. This process is called phospholipidosis and appears to be the basis of nephrotoxic injury (24-27). 


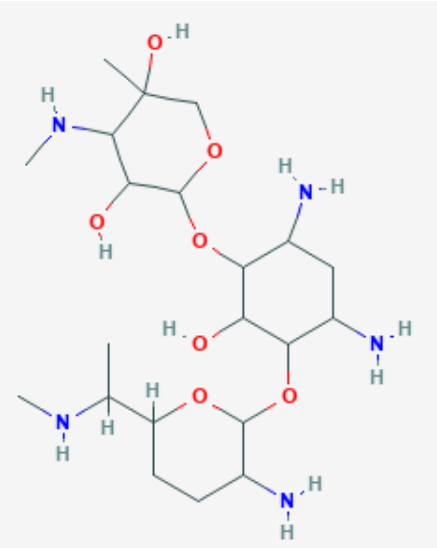

Fig. 1 Chemical structure of

Gentamicin (source PubChem)

In the control group, the average weight of the rats at baseline was $181 \mathrm{~g}$, then at $24 \mathrm{~h}$, they have presented an average of $173 \mathrm{~g}, 72 \mathrm{~h}$ an average of $169 \mathrm{~g}$, and at 7 days the average was of $172 \mathrm{~g}$.

The fact that all the animals in this group showed a weight loss during the 7th day can be explained by the blood collection maneuver that is quite stressful for the laboratory animals.

Compared to the control group, the small dose gentamicin treated group had an average body weight of $187 \mathrm{~g}$ at baseline, as at $24 \mathrm{~h}$ this was $182 \mathrm{~g}$ at $72 \mathrm{~h} 178 \mathrm{~g}$, and at 7 days averaged $182 \mathrm{~g}$. We can conclude that low dose gentamicin determined a decrease in body weight parallel to the control group.

The group receiving gentamicin $75 \mathrm{mg} / \mathrm{kg} . \mathrm{c}(\mathbf{G 2})$ had an initial mean weight of $182 \mathrm{~g}$ reaching $176 \mathrm{~g}$ at 24 hours, $172 \mathrm{~g}$ at $72 \mathrm{~h}$ and $173 \mathrm{~g}$ at $7 \mathrm{~h}$ days. As with small doses, high dose gentamicin caused a decrease in weight compared to the control group. The evolution of the three lots was parallel to control group.

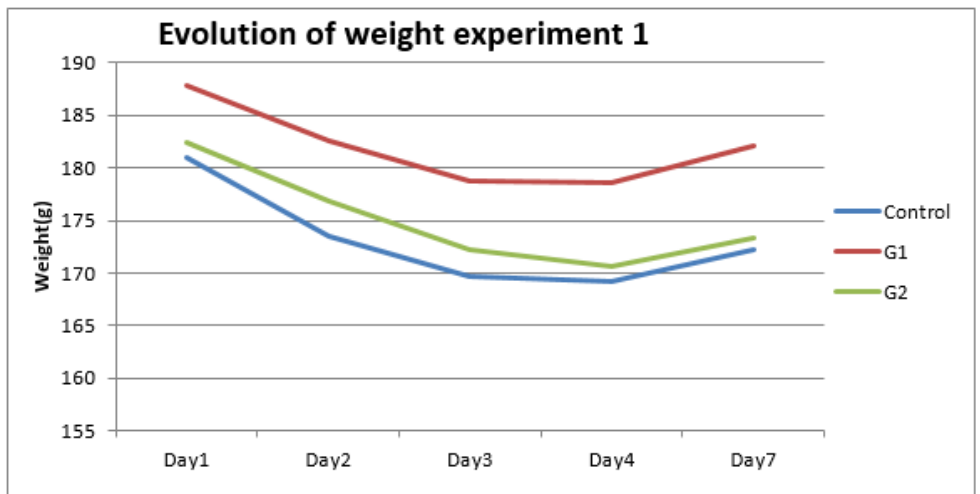

Fig. 2. Evolution of weight experiment 1

Determination of serum creatinine level and NGAL in the three studied groups

$\underline{\text { Serum creatinine }}$

Compared to the control group, the G1 group had an average serum creatinine of $0.72 \mathrm{mg} / \mathrm{dL}$ at $4 \mathrm{~h}$, at $24 \mathrm{~h}$ was $0.96 \mathrm{mg} / \mathrm{mL}$, at $72 \mathrm{~h}$ was $0.94 \mathrm{mg} / \mathrm{mL}$. We can conclude that gentamicin administered at low dose resulted in a significant increase in serum creatinine from the second day of administration compared to the control group. The lot receiving gentamicin at high dose $(\mathrm{G} 2)$ had a mean serum creatinine at the start of the experiment of $0.98 \mathrm{mg} / \mathrm{mL}$ to reach $0.92 \mathrm{mg} / \mathrm{mL}$ at $24 \mathrm{~h}$ and $1.05 \mathrm{mg} / \mathrm{mL}$ at $72 \mathrm{~h}$. As in the case of the previous group G1, in the case of group G2 the large-dose gentamicin, produced a significant increase in creatinine levels compared with the control group from $24 \mathrm{~h}$ and up to $72 \mathrm{~h}$.

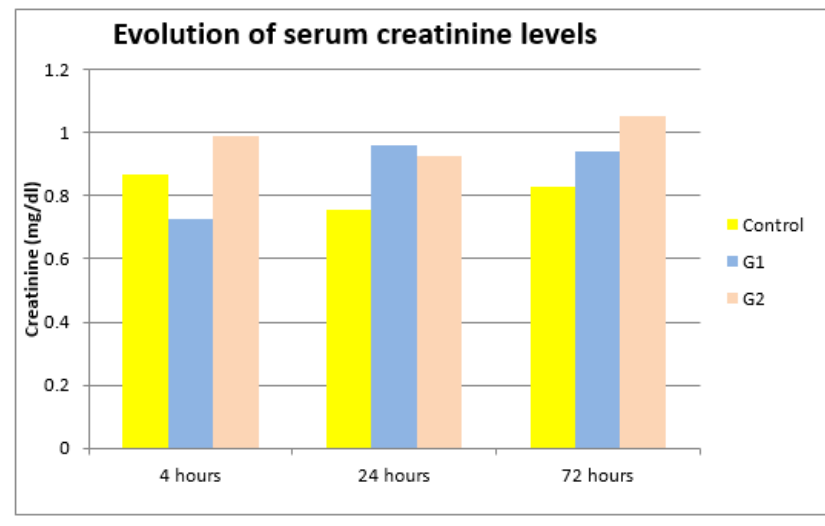

Fig. 3. Evolution of serum creatinine levels experiment 1 
Serum determination of NGAL for the three studied lots

Thus, it was observed that the group receiving gentamicin at low dose had a significant increase of mean serum value of NGAL of $899 \mathrm{U} / \mathrm{mL}$ at $4 \mathrm{~h}(\mathrm{p}<0.05)$ after the administration, at $24 \mathrm{~h}$ this was $653 \mathrm{U} / \mathrm{mL}(\mathrm{p}<0.05)$, and at 72 $\mathrm{h} 482 \mathrm{U} / \mathrm{mL}(\mathrm{p}<0.05)$. We can conclude that the low dose of gentamicin determined a significant increase in NGAL starting at 4 hours after comparative administration with control group.

The lot receiving gentamicin at high dose had a significant increase of the mean value of NGAL at the start experiment of $1773 \mathrm{U} / \mathrm{mL}(\mathrm{p}<0.05)$ to reach $1333 \mathrm{U} / \mathrm{mL}$ at $24 \mathrm{~h}(\mathrm{p}<0.05)$ and $631 \mathrm{U} / \mathrm{mL}$ at $72 \mathrm{~h}(\mathrm{p}<0.05)$. As in the previous case, in the G2 group it can be seen that gentamicin has led to an important increase in serum levels of NGAL starting $4 \mathrm{~h}$ after administration and maintaining high levels 72 hours compared to the control group.

Compared to creatinine, NGAL increased faster and was detected at elevated levels from the first $4 \mathrm{~h}$ after administration of both low and high dose gentamicin.

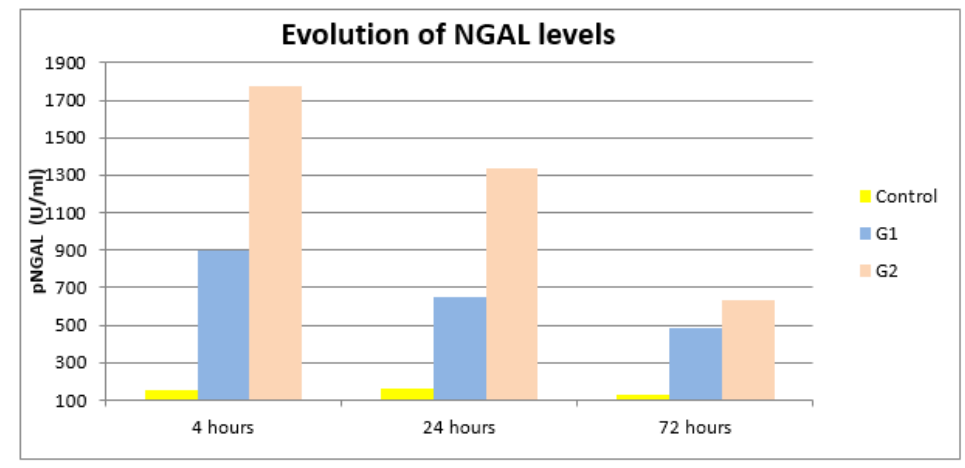

Fig. 4. Evolution of NGAL levels Experiment 1

\section{Experiment 2}

Fipronil $\left(\mathrm{C}_{12} \mathrm{H}_{4} \mathrm{Cl}_{2} \mathrm{~F}_{6} \mathrm{~N}_{4} \mathrm{OS}\right)$ is a new class phenylpyrazole insecticide used in many countries against insects that gained resistence to conventional pesticides. The toxicity of fipronil appears by acting on the GABA chloride channel in nerve mebranes resulting in increased excitability of the neurons by inhibition of chloride passage. The nephrotoxic effect of fipronil is caused mainly by inducing oxidative stress and generation of free radicals, the effects being dose dependent. The nephrotoxic injury causes cellular necrosis in the proximal tubule and interstitial fibrosis (28-31).

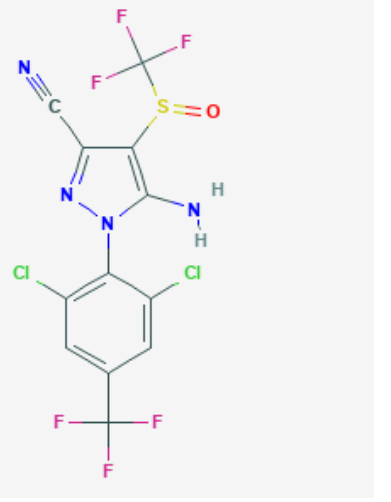

Fig. 5. Chemical structure of Fipronil (source PubChem)

Acute atropine overdose can induce an anticholinergic syndrome which manifests as both peripheral and CNS symptoms. Toxic effects can appear at therapeutic concentrations, atropine blocks the action of acethycholine at the muscarinic receptor. The smooth muscles of the bladder are considerably affected producing urinary retention. Severe atropine poisoning can produce metabolic acidosis, rhabdomyolisis and acute kidney injury. (32)

As can be seen from the above tables, for the control group, the average weight at baseline was $180 \mathrm{~g}$. Then at 24 hours, they have showed an average of $179 \mathrm{~g}$, at 72 hours an average of $178 \mathrm{~g}$ and at 7 days the average was $181 \mathrm{~g}$.

Compared to the control group, the fipronil treated group had an average body weight of $180 \mathrm{~g}$ at the initial time, at $24 \mathrm{~h}$ this was $174 \mathrm{~g}$, at $72 \mathrm{~h} 170 \mathrm{~g}$, and at 7 days have an average weight of $173 \mathrm{~g}$. We can conclude that fipronil produced a more pronounced decrease in body weight compared to the control group.

The group that received atropine had an initial average weight of $188 \mathrm{~g}$ that it would reach $184 \mathrm{~g}$ at $24 \mathrm{~h}$, respectively $182 \mathrm{~g}$ at $72 \mathrm{~h}$ and $187 \mathrm{~g}$ at 7 days. In this case the group retained a parallel evolution with the control group, the weight loss being less more pronounced than with fipronil.

Regarding the combination of fipronil - atropine it was observed that initially this group had an average weight of $185 \mathrm{~g}$, at $24 \mathrm{~h}$ to $178 \mathrm{~g}$, at $72 \mathrm{~h}$ an average weight of $172 \mathrm{~g}$, at the end of the experiment reached an average weight of $172 \mathrm{~g}$.

In conclusion, the combination resulted in a significant decrease in weight of the treated animals compared to the other groups. 


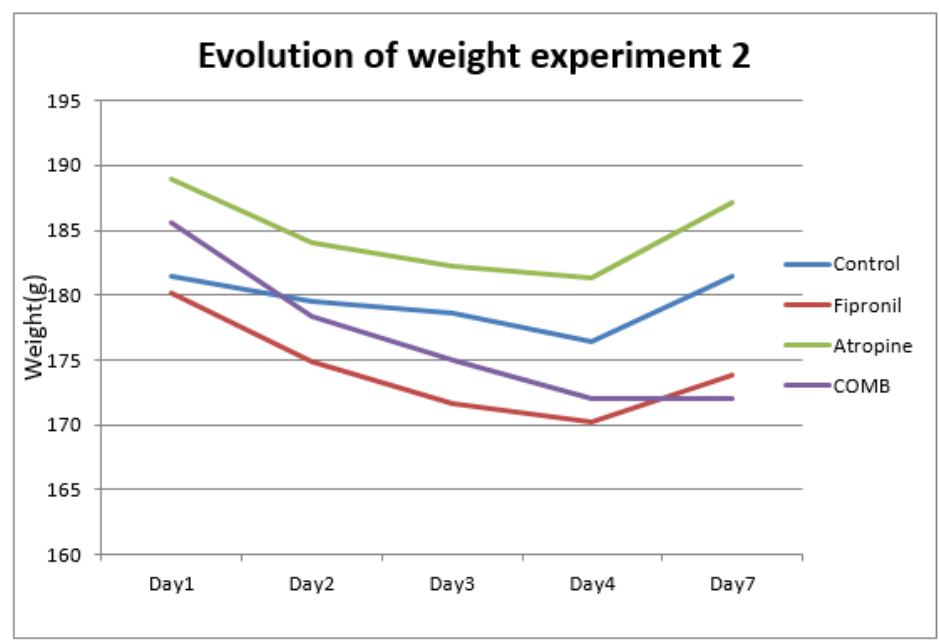

Fig. 6. Evolution of weight experiment 2

\section{Determination of serum creatinine level in the studied groups}

Compared to the control group, the fipronil-treated group had an initial average serum creatinine of $0.76 \mathrm{mg} / \mathrm{dL}$ at $24 \mathrm{~h} 0.8 \mathrm{mg} / \mathrm{dL}$ and at $72 \mathrm{~h}$ its value was $0.85 \mathrm{mg} / \mathrm{dL}$. We can conclude that fipronil has led to an increase in creatinine starting from day 2 compared to the control group.

The group that received atropine had a mean serum creatinine value at the beginning of the experiment of $0.76 \mathrm{mg}$ / dl, to remain at the same value at $24 \mathrm{~h}$, and to increase at $0.86 \mathrm{mg} / \mathrm{dL}$ at $72 \mathrm{~h}$. As with fipronil, in the the atropine treated group we observed a slight increase in creatinine compared to the control group.

Regarding the combination of fipronil - atropine it is noticeable that initially this group had a mean serum creatinine of $0.88 \mathrm{mg} / \mathrm{dL}$, at $24 \mathrm{~h}$ rised to $0.92 \mathrm{mg} / \mathrm{dL}$, and at $72 \mathrm{~h}$ recorded an average value of $0.9 \mathrm{mg} / \mathrm{dL}$. Although this combination determined the highest creatinine levels, however these values are not far exceeding the normal values.

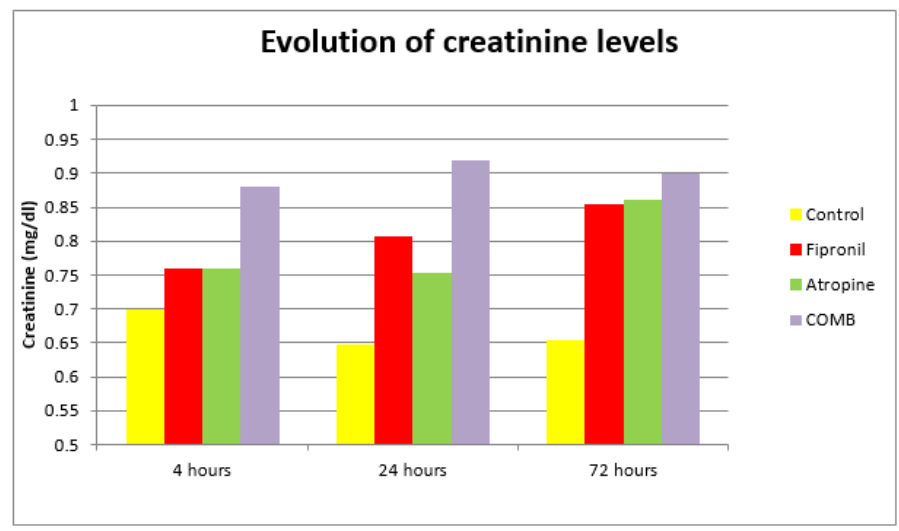

Fig. 7. Evolution of serum creatinine levels experiment 2

\section{Serum determination of NGAL for the studied groups}

The group treated with fipronil had an significant increase of serum NGAL value of $486 \mathrm{U} / \mathrm{mL}$ at $4 \mathrm{~h}(\mathrm{p}<0.05)$, as at $24 \mathrm{~h}$ this was $287 \mathrm{U} / \mathrm{mL}(\mathrm{p}<0.05)$ at $72 \mathrm{~h}$ of $198 \mathrm{U} / \mathrm{mL}(\mathrm{p}<0.05)$. We can conclude that fipronil caused an increase in NGAL serum values at $4 \mathrm{~h}$, an increase that lasted up to 24 hours and $72 \mathrm{~h}$, respectively, compared to the control group. Its highest levels were recorded at $4 \mathrm{~h}$.

The group that received atropine had a mean value of NGAL at the beginning experiment at $653 \mathrm{U} / \mathrm{mL}(\mathrm{p}<0.05)$ to reach $554 \mathrm{U} / \mathrm{mL}$ at $24 \mathrm{~h}(\mathrm{p}<0.05)$ and $262 \mathrm{U} / \mathrm{mL}(\mathrm{p}<0.05)$ respectively at $72 \mathrm{~h}$. As with fipronil, in the case of the atropine treated group, it can be observed that atropine determines increases in serum NGAL starting at $4 \mathrm{~h}$ after administration and are maintained for up to $72 \mathrm{~h}$ after administration compared to the control group.

As far as the combination of fipronil - atropine is concerned, it was observed that this group had initial a significant increase reaching levels of $742 \mathrm{U} / \mathrm{mL}$ NGAL ( $<<0.05)$, at 24 hours the level was $598 \mathrm{U} / \mathrm{mL}(\mathrm{p}<0.05)$, and at $72 \mathrm{~h}$ we recorded an average of $219 \mathrm{U} / \mathrm{mL}(\mathrm{p}<0.05)$. In conclusion, the combination caused an increase of NGAL values throughout the experiment. Compared to creatinine, NGAL increased faster and was detected at elevated levels from the first $4 \mathrm{~h}$ after administration of fipronil, atropine and the combination of them. 


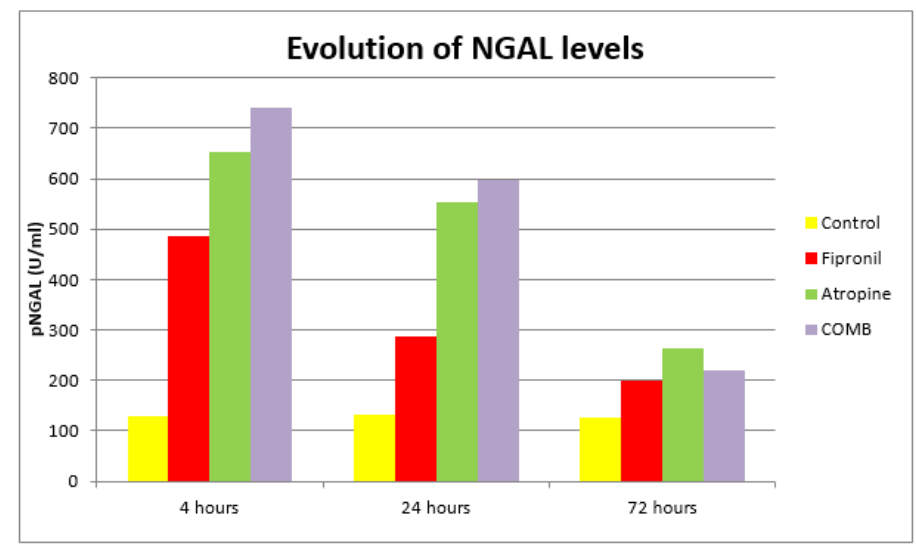

Fig. 8. Evolution of NGAL levels experiment 2

\section{Conclusions}

NGAL remains a very promising biomarker for early detection of AKI. In children poisoning it is very important to prevent the development of AKI, because it is demonstrated that renal failure worsens the patient prognosis. Our study suggests that in poisoned animal models serum NGAL raises rapidly and remains persistent elevated in severe nephrotoxic injury. Compared to creatinine it reaches higher levels early during acute poisoning. The results must be validated in clinical practice. In pediatric practice AKI si frequently underestimated and sometimes underdiagnosed. It is very important to have an early marker for AKI in pediatric practice because with proper hydration and better control of nephrotoxic drugs we could prevent the onset of toxic renal injury during hospitalization (33-37).

\section{References}

1. MEHTA, R., CHERTOW, G., J Am Soc Nephrol., Vol.14, No.8, 2003, p. 2178-2187

2. KDIGO Clinical Practice Guideline for Acute Kidney Injury. Kidney Int Suppl, Vol. 2, No. 1 , 2012, p 8-12

3. MEHTA RL, KELLUM JA, SHAH SV, et al., Crit Care, Vol. 11, No. 2, 2007, R31

4. KAI M. SCHMIDT-OTT, KIYOSHI MORI, JAU YI LI, AVTANDIL KALANDADZE, DAVID J. COHEN, PRASAD DEVARAJAN, JONATHAN BARASCH., JASN, Vol.18, No. 2, 2007, p407-413

5. DU ZP, WU BL, WU X, et al. Sci Rep Vol. 5 No. 12010, 2015, p1-14

6. FLOWER, DR., Biochim Biophys Acta, Vol.1482, 2000, p46 -56

7. GOETZ DH, HOLMES MA, BORREGAARD N, BLUHM ME, RAYMOND KN, STRONG RK, Mol Cell Vol.10, No.5, 2002, 1033 -1043

8. FLO TH, SMITH KD, SATO S, RODRIGUEZ DJ, HOLMES MA, STRONG RK, AKIRA S, ADEREM A, Nature Vol.432, No.7019, 2004, p. 917 -921

9. LAKSHMI B, MISHRA M, SRINIVASAN N, ARCHUNAN G. PLoS One. Vol. 10, No. 8, 2015, e0135507

10. SUBHANKAR CHAKRABORTY, SUKHWINDER KAUR, ZHIMIN TONG, SURINDER K. BATRA, SUSHOVAN GUHA, Prof. Francisco Veas (Ed), Intech, 2011, p345-368

11. SABBAHY ME VAIDYA VS, Wiley Interdiscip Rev Syst Biol Med Vol. 3, No.5 2011, p. 606-618

12. MISHRA J, MORI K, MA Q, J Am Soc Nephrol, Vol. 15, No.12, 2004, p 3073-3082

13. GONG L, YU, H, ZHUGE Y, YU Q. Ren Fail, Vol. 34, No. 6, 2012, p. 777-783

14. SHUXIAN AN, XIUJUAN ZANG, WEIJIE YUAN, YIFENG ZHUGE, QING Y., Ren Fail Vol. 35 No. 1, 2013, p. 143-149

15. ABELLA V, SCOTECE M, CONDE J, et al, Biomarkers.; Vol. 20, No.8, 2015, p. 565-571

16. JAMIE R. PRIVRATSKY, JIANDONG ZHANG, XIAOHAN LU, NATHAN RUDEMILLER, QINGQING WEI, YEN-REI YU, MICHAEL D. GUNN, STEVEN D. CROWLEY, Am J Physiol Renal Physiol. Vol. 315 No. 3, 2018, F682-F691

17. NAHUM E, KADMON G, KAPLAN E, WEISSBACH A, HIJAZI H, HASKIN O, MOZER-GLASSBERG Y, J Crit Care. Vol 50, 2019, p275-279

18. XIN XU, SHENG NIE, AIHUA ZHANG, JIANHUA MAO, HAI-PENG LIU, et al Clin J Am Soc Nephrol. Vol. 13, No. 12, 2018, p. 1791-1800

19. CICCIA E., DEVARAJAN P., Int J Nephrol Renovasc Dis. Vol10, 2017, p. 77-84.

20. HARADA, R., ISHIKURA, K., SHINOZUKA, S. et al. Clin Exp Nephrol Vol. 22, 2018 p. 938

21. ZHOU F, LUO Q, WANG L, HAN L., Eur J Cardiothorac Surg. Vol. 49, No.3, 2016, p 746-755

22. KARI JA, SHALABY MA, SOFYANI K, SANAD AS, OSSRA AF, et al World J Pediatr. Vol 14, No. 2, 2018, p.134-142

23. AHMAD KADDOURAH, M.D., RAJIT K. BASU, M.D., SEAN M. BAGSHAW, M.D., AND STUART L. GOLDSTEIN, M.D, N Engl J Med, Vol. 376, 2017 , p.11-20

24. LUO QH, CHEN ML, CHEN ZL, HUANG C, CHENG AC, FANG J, TANG L, GENG Y. Kidney Blood Press Res. Vol. 41 No. 6, 2016, p. 911 -918.

25. JOSE M. LOPEZ-NOVOA, YAREMI QUIROS, LAURA VICENTE, ANA I. MORALES, FRANCISCO J. LOPEZ-HERNANDEZ, Kidney International, Vol 79, No. 1,2011, p. 33-45.

26. KIM S, LESHERPEREZ SC, KIM BC, YAMANISHI C, LABUZ JM, LEUNG B, TAKAYAMA S., Biofabrication, Vol. 8 No. 1, $2016,015021$.

27.NATIONAL CENTER FOR BIOTECHNOLOGY INFORMATION. PubChem Database.Gentamicin,CID=3467,https:// pubchem.ncbi.nlm.nih.gov/ compound/Gentamicin (accessed on June 10,2019)

28. RATRA GS, CASIDA JE. Toxicol Lett; Vol.122 No.3, 2001 p. 215-22.

29. RATRA GS, ERKKILA BE, WEISS DS, CASIDA JE. Toxicol Lett, Vol. 129 No. 1-2, 2002, p.47-53.

30. TINGLE CC, ROTHER JA, DEWHURST CF, LAUER S, KING WJ. Rev Environ Contam Toxicol., Vol. 176, 2003, p. 1-66.

31. NATIONAL CENTER FOR BIOTECHNOLOGY INFORMATION. PubChem Database. Fipronil, CID=3352, https://pubchem.ncbi.nlm.nih.gov/compound/ Fipronil (accessed on June 10, 2019) 
33. RONCO C. N-GAL, Crit Care., Vol. 11, No. 6, 2007, p 173

34. GOLDSTEIN SL, MOTTES T, SIMPSON K, Kidney Int , Vol. 90, 2016 p. 212.

35. SLATER MB, GRUNEIR A, ROCHON PA, et al., Paediatr Drugs, Vol. 19, 2017, p. 59.

36. ONOFREI, S.D, RADULESCU, D.,PERIDE, I, et al., Rev. Chim., 70 , no. 4, 2019, p. 1268-1271

37. DMOUR, R.; TARTAU, L.M., SINDILAR, A, et al. Rev. Chim., 69, no. 7, 2018, p 1744-1748

Manuscript received: 18.06.2019 